\title{
o Código Filipino, as Normas Camarárias e o comércio: mecanismo de vigilância e regulamentação comercial na Capitania do Rio Grande do Norte
}

\author{
Filipino Code, municipalities and trade: \\ mechanism for monitoring and regulating \\ trade in the Captaincy of Rio Grande do Norte
}

Thiago Alves Dias*

\section{Resumo}

$\mathrm{O}$ artigo propõe apresentar algumas considerações acerca das normas metropolitanas encetadas pelo Código Filipino e sua relação com a atuação do poder local municipal representado pelas Câmaras, notadamente, nos aspectos relacionados à vigilância e à regulamentação das práticas comerciais cotidianas. Partindo dos registros das Câmaras Municipais da Capitania do Rio Grande do Norte, evidenciamos a relação entre poder central e poderes locais com base nas normas, na vigilância e na regulamentação do comércio e das práticas mercantis na Capitania.

Palavras-chave: Código Filipino; Câmaras Municipais; comércio.

\begin{abstract}
The article aims to present some considerations concerning the metropolitan standards undertaken by Filipino Code and its relation to the performance of local city represented by the chambers, especially in aspects related to supervision and regulation of daily business practices. Based on the records of the Municipal Councils of the Province of Rio Grande do Norte, we evidence the relationship between central government and local authorities from the standards, monitoring and regulation of trade and commercial practices in the province.
\end{abstract}

Keywords: Filipino Code; Municipalities; trade.

O Código Filipino passou a vigorar em Portugal e suas possessões ultramarinas a partir da sua primeira impressão e promulgação, ocorridas por volta de 1603. O Direito Civil português encerrado nas Ordenações Filipinas recebeu influência do Direito Romano, do Direito Canônico, de acordos entre os Reis

* Doutorando em História, Universidade de São Paulo (USP). dias.thiagoa@gmail.com 
Católicos ibéricos e o papado romano, dos costumes antigos dos povos ibéricos, com abertura para determinadas prerrogativas locais, além de contar com decisões assentadas nas reuniões da Casa da Suplicação e do Porto. Para Cândido Mendes, o Código Filipino "seguiu, no método e sistematização das matérias, o Código Manoelino, e a quase totalidade das disposições deste estão aí incorporadas; mas contém muitas outras extraídas das reformas feitas durante todo o século XVI". Sendo tributário dos códigos anteriores, o Filipino guardava certas especificidades ideológicas que podem estar relacionadas, entre outros fatores, às mudanças propostas e aceitas pelos Reis Católicos com a promulgação das reformas da Igreja acordadas no Concílio de Trento (15461562) (Almeida, 2004, p.23).

Além de incorporar os assentos morais cristãos acordados no Concílio, o Código Filipino foi produzido também para responder às inquietações dos administradores e funcionários monárquicos e aos próprios ditames do rei acerca das novas possessões coloniais. O Código acabou reunindo em um só corpo legal as chamadas leis extravagantes, promulgadas, em abundância, no transcurso do século XVI para dar suporte jurídico ao contexto iniciado com a descoberta de novos mercados coloniais.

Dos cinco livros que compõem o Código, o primeiro será o mais discutido neste momento, posto que esse livro contém, prioritariamente, o regimento dos magistrados e oficiais da justiça com todos os seus deveres, direitos e atribuições, assim como diretrizes para sua forma de atuação. Os direitos e deveres dos oficiais do Senado da Câmara (juiz, vereador, procurador e tesoureiro) e dos funcionários (porteiro, pregoeiro, escrivão e carcereiro), e também matéria sobre os pesos e medidas, taxações e impostos aparecem nesse livro.

Com o fim da União Ibérica, estava aberta a possibilidade para uma recopilação da legislação ou, até mesmo, a fundamentação de um novo código compatível com os tempos vividos pela monarquia portuguesa naquele momento. No entanto, um novo código não foi produzido, mas muitas leis extravagantes foram lançadas.

Na introdução de um compêndio de auxílio à leitura e análise do Código Filipino publicado em 1869, Cândido Mendes chama a atenção para o fato de que não havia nenhuma edição brasileira do Código Filipino, fato esse que só iria mudar em 1870. O autor afirma que ninguém nunca se dispôs a publicar o Código no Brasil, provavelmente "temendo os gastos da empresa e a reforma total da Legislação ali consignada” (Almeida, s.d., p.5). Todas as edições do Código que vieram ao Brasil foram trazidas da Europa. Esse dado é importante para mensurarmos as dificuldades de obtenção da cópia do Código e atentar 
para as formas de circularidade das normas e leis oriundas do Reino para com suas possessões. A questão do acesso e permanência de uma cópia do Código Filipino na Câmara de Natal exemplifica essa questão.

Com o fim da ameaça holandesa e a restauração do poder lusitano em 1659, o Senado da Câmara de Natal passou a ser o órgão administrador oficial a serviço da metrópole. Sendo assim, em 29 de dezembro de 1682, os camaristas "decidiram que fossem retirados numerários para comprar uma Ordenação, por não haver uma neste Senado". ${ }^{1}$ Quase um mês depois dessa decisão de compra do Código, os camaristas mais uma vez atentam para necessidade da aquisição de uma cópia. Em 21 de janeiro do ano seguinte, levando em consideração as ordens oriundas da Comarca da Paraíba, "que tratava sobre o melhoramento do Conselho e seu Povo, os oficiais mandaram que se desse a execução de tudo que se deve ao Senado para que se adquirisse um Livro das Ordenações, por ser necessário à Casa da Câmara". ${ }^{2}$

Não encontramos menção direta que possibilitasse afirmar categoricamente quando a Câmara de Natal adquiriu de fato uma cópia do Código. Todavia, alguns outros documentos reportam que uma cópia foi adquirida. Isso porque, em 16 de outubro de 1723, foi registrada num Termo de Correição da Câmara de Natal a "ordem do Ouvidor Geral para que o Escrivão lesse o título 66 da Ordenação e mostrasse esse registro aos novos Vereadores no dia de sua posse", intentando que "cumprissem suas obrigações". No mesmo documento, o escrivão registrou um reforço para essa ordem do Ouvidor, afirmando mais que "desse conhecimento do título 66 da Ordenação na posse dos Vereadores, para que cumprissem a contento com suas obrigações". ${ }^{3} \mathrm{O}$ Título 66, ao qual o Ouvidor se refere, encontra-se no Tomo I, Livro I, contendo cinquenta parágrafos sobre os direitos e deveres do vereador. ${ }^{4}$

Em outro Termo de Vereação, que atesta a existência das Ordenações na Câmara de Natal, em 1798, o almotacé da cidade do Natal entrou em confronto com o almotacé do Termo da cidade, em que ambos questionavam a atitude um do outro. Um deles foi "chamado à Câmara e lhe mandaram ler o título dos Almotacés na Ordenação". ${ }^{5}$

Munidos do Código Reinol, as Câmaras da Capitania podiam melhor regular e vigiar as práticas mercantis. Pretendendo aprofundar a discussão sobre códigos reinóis, prática camarária e comércio, passaremos, neste momento, a analisar as câmaras da Capitania do Rio Grande do Norte e sua atuação na regulamentação e vigilância das práticas comerciais.

As licenças de comércio para abertura de lojas e práticas de ofício, emitidas pela Câmara, constituíam um dos primeiros dispositivos de regulamentação 
mercantil. Isso porque elas deveriam ser requisitadas em Câmara logo no início do ano, como rezava o Código.

Em janeiro de 1682, o Senado da Câmara de Natal resolveu que todo aquele que "vendesse fazendas secas e exercesse ofício e não tirasse as devidas licenças no mês de Janeiro" seria condenado em $2 \$ 000$ réis. ${ }^{6}$ Esse mandado deveria funcionar como um reforço das prerrogativas já ditadas nas próprias posturas, tendo em vista que, alguns anos antes, em meados do ano de 1679, a Câmara deliberou "que as pessoas que vendiam aguardentes, vinhos e produtos secos e molhados, assim como os que exerciam ofícios, tirassem suas licenças no prazo de um mês, com penas acertadas pelos oficiais anteriores". ${ }^{7}$ Sendo assim, estava previsto pelos editais e acordos camarários que as licenças de abertura de lojas e de ofícios careceriam ser regularizadas logo no início do ano, tendo em vista a sua gerência e vigilância por parte da Câmara durante todo o ano.

As demais câmaras da Capitania precisariam seguir o exemplo de sua congênere em Natal, já que o Senado da Câmara de Portalegre acabou condenando "Ana Maria Cabral, Miguel Pereira, Manoel Soares e Cosme Teixeira em $1 \$ 000$ réis cada um por não terem tirado licença para se venderem suas vendas e tecerem plumas de algodão tendo para isso sido notificado em correição e não obedeceram". ${ }^{8}$

Tal como os proprietários de lojas e tabernas eram obrigados a ter licenças para abertura de comércio, os oficiais de ofícios mecânicos também necessitavam de licenças para o exercício do ofício e a venda dos itens produzidos. De ofícios e conhecimento especializado, os mestres, oficiais ou aprendizes de sapateiro, ourives e alfaiates, por exemplo, deveriam registrar-se na Câmara e tirar sua licença. Para a vigilância dos oficiais especializados e da qualidade de seus produtos ofertados, a Câmara passava provisão a um Juiz de Ofício. ${ }^{9}$

Num registro de licença de Juiz de Ofício de Sapateiro da Cidade de Natal, o "mestre e oficial mais capaz Ignácio de Mello" é registrado como o juiz de seu ofício em 1782, sendo que "no ofício de sapateiro cotidianamente necessário deviam aplicar-se" a inteligência e idoneidade de seu julgar e "dele usar os que dissessem [ter] a requisita inteligência e suficiência" para serem sapateiros, "guardando-se a lei e regimento deste Senado". ${ }^{10}$ Assim, o Juiz de Ofício de Sapateiro, como qualquer outro juiz de ofício, constituía mais um dos mecanismos institucionais de regulamentação do comércio - eles iriam visitar as lojas e casas dos companheiros de ofício, e de lá e de seus produtos averiguariam sua capacidade de exercer tão antigo exercício técnico realizado sobre 
couro, cordas, agulhas e tesouras. O espaço institucional, portanto, estende seus braços sobre os ateliês, casas e oficinas diversas.

Ao analisarmos o "Mapa dos oficiais de ofícios mecânicos" datado de 1827, constatamos que havia nesse período 132 sapateiros entre mestres, oficiais e aprendizes, distribuídos por toda a Capitania. ${ }^{11}$ Embora o maior produtor de couro tenha sido o sertão colonial, estabeleceram-se, no litoral, seus mais significativos beneficiadores, como o sapateiro, por exemplo. Representando $84 \%$ dos oficiais totais desse segmento na Capitania, esses homens e mulheres manejaram o couro, fosse ele de boi, bode ou veado, cortaram tiras e talões, fizeram chinelos e sapatos diversos.

Importante também notar que, de acordo com os mapas de importação da Capitania, entre os anos de 1811 e 1813 aportaram 259 navios carregados de tesouras e navalhas. ${ }^{12}$ No ano de 1811, a Vila de São José recebeu duzentas tesouras, e Extremoz, 120 facas (Lopes, 2005, Anexos, Tabela 19, p.185), ambas vilas litorâneas. Pelo menos em 1811, nenhum desses produtos seguiu para as vilas e localidades sertanejas; ficaram as tesouras e as facas no litoral para a confecção de sapatos e chinelos com o couro vindo do sertão. Depois de tantos sapatos produzidos e muitos pés calçados na Capitania, outros tantos seguiam dos portos litorâneos em busca do comércio intracolonial ou além-mar.

De acordo com o Regimento do Ofício de Sapateiro de 1791, feito em vereação na Câmara de Natal, "todos os oficiais desse ofício devem ter" a listagem dos valores dos sapatos, chinelos e botas, especificados por tipo de material utilizado, tamanho e formato, além de constar quanto custa o material e quanto custa o trabalho do oficial, "nas suas tendas a vista do povo como determinaram os senhores oficiais da Câmara". ${ }^{13}$ A Câmara regulava não só o preço dos produtos advindos das oficinas dos sapateiros, como determinava quanto eles deviam ganhar por peça feita e vendida.

Os produtos feitos de cordovão custavam, em média, 10\% mais caro que os produtos fabricados com couro de veado e $20 \%$ mais caro que aqueles de cabra, por exemplo. Outros detalhes, nos calçados, também faziam diferença de preço, como o talão. Este é a parte que assenta sobre o calcanhar formando um salto, sendo cosido à peça que faz o formato do pé. Com cadarços ou sem, rasos ou com talão, furados ou forrados, para homens, mulheres ou crianças, qualquer que fosse o modelo ou tamanho, a Câmara fez questão de arrolar e arregimentar seu preço de venda e o ganho do sapateiro sobre o produto.

A cobrança dos impostos e taxas sobre a produção e comércio visava, além de garantir o fluxo corrente das riquezas coloniais para a Metrópole, regulamentar a prática cotidiana comercial dos vassalos. Implicava, portanto, que 
todos aqueles que desejassem realizar práticas mercantis deveriam estar cientes de que, para isso, necessitariam arcar com a tributação real. Sendo assim, a própria existência e as cobranças dos impostos já implicam a regulamentação desse comércio. Comerciar, além de representar possibilidade de ascensão social, era também aceitar as prerrogativas inerentes à prática e, acima de tudo, estar sob a égide da Coroa e seus mecanismos de regulamentação.

Dos impostos instituídos pela Coroa podemos dividi-los em tributos eventuais (Paz da Holanda, Finta da Rainha, Benefício do Banco do Brasil etc.) e permanentes (Dízimo, Quintos, Sisa etc.). Dos diferentes impostos cobrados na América portuguesa e estabelecidos durante quase toda a totalidade do período colonial, boa parte deles foram condicionados às práticas comerciais.

Três tipos de contribuições podem exemplificar a discussão sobre impostos enquanto regulamentação do comércio: Direitos de Entrada, Direito de Passagem e o Benefício do Banco do Brasil. Nessa seleção, levamos em consideração a capacidade de mensuração da relevância dos entroncamentos mercantis da Capitania do Rio Grande do Norte a partir da regulamentação que havia sobre a entrada e saída de pessoas, animais e produtos, assim como o fluxo dessa mercadoria a partir das passagens sobre estradas e rios. Da mesma forma, a questão do imposto instituído em 1812, para a criação do Banco do Brasil, enuncia a dimensão do comércio e das práticas mercantis da Capitania.

O imposto sobre as entradas foi instituído no intuito de legitimar a soberania institucional e fronteiriça de cada Capitania, controlar o comércio intracolonial e angariar recursos para a Fazenda Real, além de controlar os furtos de gado. Dessa forma, todos que entrassem ou saíssem da Capitania, com mercadorias ou animais, deveriam pagar os devidos tributos. Para o não pagamento do imposto, no momento da entrada ou saída da Capitania era indispensável ter efetivado o registro e recebido a licença do Senado da Câmara. Caso contrário, oficial competente, conhecido como Registrador, procedia à autuação do indivíduo.

Já o imposto sobre as passagens era cobrado, sobretudo, como uma espécie de pedágio para a travessia de rios e lagoas por aqueles que não possuíam embarcações. Comumente, as passagens de rios e lagoas realizadas pelas embarcações eram conferidas em arrematação ou concessão a terceiros, que acabavam pagando à Câmara o direito de possuírem a "passagem" de determinado rio ou lugar de difícil travessia, por exemplo.

No caso da Capitania do Rio Grande do Norte, os impostos de entrada e passagem muitas vezes acabam se imbricando, haja vista que algumas das principais entradas da Capitania, na Ribeira do Assu ou do Potengi, localizavam-se 
no delta dos rios Piranhas e Potengi, respectivamente, requerendo, muitas vezes, uma entrada em embarcação. Ainda no século XVII, encontramos os primeiros registros a respeito dos impostos de entrada e passagem da Capitania.

Identificamos, na leitura e análise dos Termos de Vereação do Senado da Câmara de Natal, que a passagem da Ribeira de Natal, ou seja, da travessia do rio Potengi, foi motivo de preocupação por parte da Câmara durante todo o período colonial, dada a relevância desse contrato para as práticas mercantis da Capitania.

Durante aproximadamente 10 anos, o alferes Antônio da Silva de Carvalho teve a prerrogativa de dar passagem no rio Potengi a diversos homens, mulheres, crianças, escravos e animais, no entanto, é possível que Antônio da Silva de Carvalho, durante todos os anos nos quais esteve responsável pela passagem da Ribeira, nunca tenha realizado um trabalho satisfatório aos olhos do Senado da Câmara. Em 1711 e 1713, foi lembrado, em vereação, de suas obrigações quanto à manutenção de canoas para a passagem da Ribeira ${ }^{14} \mathrm{e}$, mesmo assim, em 1717, mais uma vez o Senado da Câmara de Natal voltava a notificá-lo por seu serviço prestado. Porém, dessa vez, a Câmara alegava ter recebido reclamações do povo e de outras câmaras, ${ }^{15}$ provavelmente das câmaras litorâneas próximas a Natal, como Extremoz, Vila Flor, São José ou Arez.

Datam de 1719 as duas últimas evidências que atestam Antônio da Silva de Carvalho no mau gerenciamento do direito de passagem da Ribeira - uma em junho, notificando que ele "tivesse sempre canoa pronta e se não o fizesse seria condenado em $6 \$ 000$ réis e quinze dias de Cadeia"; ${ }^{16}$ e outra, em setembro, na qual a Câmara avisava que ele "não faltasse com a passagem do rio aos passageiros". ${ }^{17} \mathrm{O}$ caso de Antônio da Silva de Carvalho ilustra bem a preocupação da Câmara com o acesso à Capitania por aqueles que necessitavam atravessar o rio Potengi, chegando à sede do governo da Capitania.

Soma-se aos mecanismos de regulamentação institucional camarária mercantil o imposto sobre os registros de entrada e saída de bens e produtos da Capitania, assim como a figura responsável por essa regulamentação cotidiana, o Registrador. Para a legislação metropolitana, os registros eram "estabelecimentos, verdadeiras alfândegas à beira de vias fluviais e terrestres que tinham, por objetivo, a arrecadação dos direitos", como nos caminhos do trânsito de tropas de gado, por exemplo. "Os registros eram sujeitos a rigorosos regimentos, a fim de que fosse evitado, sobretudo por omissão dos seus encarregados, o descaminho de quaisquer direitos devidos ao Erário Real"; já a competência do registro ficava a cargo do Provedor do registro que, além de manter-se vigilante, deveria 
tomar nota do dia, mês e ano em que o tropeiro registrou a passagem de tantos animais e a sua qualidade (Westphalen, 1994, p.691-692).

Em 1684, o Senado da Câmara de Natal resolveu que todo o gado, levado para fora da Capitania, precisaria ser registrado - caso fosse levado a Pernambuco, deveria pagar $\$ 480$ réis por direito de passagem. ${ }^{18}$ Poucos anos depois, o Senado deliberou que a "retirada de gado da Capitania só seria feita mediante licença previamente tirada no Senado - e unicamente dele -, caso contrário, pagaria multa de $3 \$ 000$ réis ao Registrador”, e, se o próprio Registrador "permitisse a saída irregular de uma única rês", seria ele quem pagaria a multa. ${ }^{19}$ A saída do gado da Capitania deveria ser vigiada, pelos registradores do gado, em todas as estradas e caminhos utilizados pelos tangerinos que conduziam as boiadas, sobretudo em períodos de estiagens.

Um dos caminhos antigos utilizados para sair da Capitania, direcionado ao sul, era o caminho de Tamatanduba, situado entre as atuais cidades de Pedro Velho e Canguaretama (RN), usado normalmente pelos tropeiros e tangerinos para conduzir o gado a Pernambuco. Em 1674, o governador de Pernambuco, Matias de Albuquerque, informou à Câmara de Natal que "o registro das marcas do gado que saía da Capitania não estava sendo feito, causando prejuízo", sendo convocado um morador em Tamatanduba para fazer esse registro e evitar furtos durante a condução do gado. ${ }^{20}$ Passados 4 anos desde essa regulamentação do caminho de Tamatanduba, os "moradores e criadores de gado se queixaram à Câmara sobre o registro das marcas do gado que se levava para Pernambuco que tinha que ser feito em Tamatanduba”. O protesto ocorreu porque "o povo não queria que este registro fosse obrigatório, [já que] eles tinham que pagar por cada lote $\$ 320$ réis e muitas vezes as reses eram furtadas no caminho". Os furtos nos caminhos de gado para Pernambuco deveriam ser consideráveis, já que os oficiais da Câmara resolveram "que todo criador estava isento de registrar o gado de suas fazendas, estando obrigado apenas a tirar licença na Câmara para levar o gado para fora da Capitania, com pena de pagar $4 \$ 000$ réis se não o cumprisse", ${ }^{21}$ no entanto, essa diretriz foi logo revista já que poucos anos depois o Senado da Câmara resolveu que todos aqueles que viessem à Capitania adquirir gado teriam de passar pelo caminho de Tamatanduba e pagariam no registro $\$ 50$ réis por cabeça, "mesmo que tivesse a licença, sem a qual pagaria $6 \$ 000$ réis de condenação". ${ }^{22}$

Diante da regulamentação, emitida pela Câmara para o efetivo controle dos bens e produtos que saíam da Capitania, constituía encargo do Registrador realizar essa vigilância e cobrar os impostos devidos nos locais adequados. No ano de 1750, o Senado da Câmara de Natal resolveu nomear registradores de 
boiadas para os lugares de Assu, Utinga e Cunhaú, os quais deveriam cobrar os impostos dos rebanhos que se destinavam à praça mercantil de Natal ou a outros lugares. Ocorre que a Câmara decidiu que esses registradores nomeados, "por serem pessoas fidedignas e com bom conhecimento das marcas" de ferro utilizadas nos bois e identificando a que fazenda pertenciam, "pagar por cada registro de boiada $\$ 400$ réis para o Registrador e $\$ 240$ réis para o Escrivão da Câmara pela licença que o Senado deve dar". ${ }^{23}$

Tal era o controle por parte da Câmara, que o aumento populacional e as mudanças promulgadas pelo Estado português pontearam a Capitania do Rio Grande do Norte com registradores, vilas e câmaras para a vigilância das práticas comerciais, das entradas, das saídas e das passagens no espaço institucional. Porém, tão excessivo era esse controle que os comerciantes, sempre em busca de mercados mais rentáveis e longe das taxações e impostos, encontravam formas de lesar a Coroa, buscando caminhos diferentes longe dos Registradores, feiras em outras Capitanias e pouso em outras paragens menos institucionalizadas pelo braço gerencial do poder reinol.

De qualquer forma, o gado não foi o único a ser controlado pelos dispositivos institucionais coloniais. $\mathrm{O}$ desenvolvimento da atividade algodoeira encontrou, nas terras secas da Capitania do Rio Grande do Norte, sobretudo a partir de 1776, forte recepção, além de ter constituído uma alternativa de ocupação econômica para grande parcela da população, formada por aqueles que haviam sido excluídos pelo sistema açucareiro implantado na América portuguesa, tais como homens e mulheres, pobres, livres ou escravos.

Como esperado, diante de uma economia colonial em ascensão na América portuguesa, levas de escravos africanos desembarcaram nos portos de Recife e seguiram para as lavouras algodoeiras da Capitania. De acordo com o "Mapa geral de todas as Vilas e Lugares" de 1763, consta a existência de 15 escravos na Missão de Guajiru, às vésperas de ser erigida em Vila de Extremoz em $1760 .{ }^{24}$ Embora esse mapa de 1760 faça referências a todas as outras vilas fundadas na Capitania do Rio Grande do Norte em vários aspectos, somente a Missão de Guajiru, que iria ser transformada na Vila de Extremoz, no momento de sua criação, possuía escravos. Mas num mapa populacional de 1805, pouco menos de 50 anos depois da fundação das novas vilas, já havia um contingente significativo de escravos nelas. ${ }^{25}$

Depreendemos da análise desse registro que as cinco novas vilas criadas na Capitania do Rio Grande do Norte a partir dos antigos aldeamentos indígenas possuíam em 1805 escravos e escravas em quantidades relevantes, considerando que, em 1760, somente a Missão de Guajiru - futura Vila de Extremoz 
- fez menção a 15 escravos, nos dados populacionais do período. Embora as informações populacionais, para escravos na Vila de Extremoz, estejam atreladas à Cidade do Natal e a Arez, os minguados 15 escravos de 1760 transformaram-se, em 1805, após o surto algodoeiro de 1776, em um contingente de 2.144 escravos.

Em uma análise mais apurada dos dados, caso somemos a população escrava contida no litoral teremos 2.314 homens e mulheres, enquanto as duas únicas vilas do sertão, mencionadas no documento, juntas têm 2.272 escravos. Ao fazermos um cálculo simples e adicionarmos o número de escravos do litoral e dividirmos pela quantidade de localidades, teríamos uma média de 462 escravos por vila e na cidade do Natal. Fazendo esse mesmo exercício com as únicas duas vilas do sertão mencionadas, teremos nada mais do que 1.136 escravos, ou seja, quase setecentos escravos a mais em cada vila sertaneja aludida. Sendo assim, o número de escravos e escravas que seguiram para as regiões sertanejas da Capitania do Rio Grande do Norte ultrapassou em dezenas o número de escravos que seguiam para a região litorânea.

Entende-se que o número elevado de escravos no sertão da Capitania do Rio Grande do Norte esteja atrelado ao desenvolvimento de atividades produtivas em fazendas pecuaristas que combinaram o uso da terra com a produção algodoeira, em alguns casos. Noutros, dado o atrativo econômico que a cotonicultura representou, as terras foram destinadas ao algodão e eles trabalharam exclusivamente nos algodoais. No biênio 1762-1763, o número de escravos contabilizados na Capitania do Rio Grande do Norte foi de 4.499 homens e mulheres; em 1805, essa cifra aumentou para 4.586 e praticamente dobrou entre 1811 e 1813, alcançando a soma de 8.155 homens e mulheres sob condição cativa. ${ }^{26}$ Tão expressiva era a produção algodoeira da Capitania que, em 3 de fevereiro de 1820, d. João VI decretou a criação da Alfândega do Algodão na cidade do Natal. As motivações para o estabelecimento de tal instituição estão declaradas no documento: para que não se perca a boa qualidade do algodão e não se diminua, consequentemente, a sua extração. ${ }^{27}$

No afã de controlar a produção algodoeira que seguia para as praças mercantis das Capitanias vizinhas sem realizar o pagamento devido do dízimo, a Junta da Fazenda Pública resolveu estabelecer nas passagens e lugares da Capitania do Rio Grande do Norte "registros de Portos Secos para por eles serem fornecidos as competentes guias aos condutores de algodão que desta referida Província as transportam aos mercados” de Ceará, Paraíba e Pernambuco, "para com esta nota serem apresentados nesta Junta, para na respectiva contadoria se poder proceder competente escrituração, e com 
conhecimento das quantias existentes nas diferentes caixas se possa encontrar o que houver produzido o referido Dízimo". ${ }^{28}$

Francisco Ribeiro da Silva, num estudo sobre o fiscalismo e funcionamento das alfândegas lusitanas, afirma que as cobranças regulamentadas e as formas de arrecadação de impostos sobre importação e exportação de forma sistemática, em Portugal, são criações modernas, notadamente a partir de 1587 (Silva, 2002, p.208). Diante das diversas taxas alfandegárias instituídas e dos pontos estratégicos de escoamento, recebimento e cobrança de impostos de mercadorias, surgiu em Portugal uma distinção entre as alfândegas de Portos do Mar ou Molhadas e as de Portos Secos. As alfândegas de Portos do Mar eram aquelas litorâneas e de comércio volumoso, sobretudo, em Lisboa e Porto; já os Portos Secos eram alfândegas distribuídas nas imediações fronteiriças com a Espanha, localizadas em lugares estratégicos, como rotas mercantis carroçáveis ou mesmo rios volumosos trafegáveis, como o Tejo ou o Douro (ibidem).

Conforme ofício de 27 de março de 1822 - redigido pelo escrivão da Alfândega do Algodão e enviado ao Ouvidor da Comarca da Paraíba e ministros da Fazenda Pública do Ceará ${ }^{29}$-, foram designados para a Capitania 21 registradores de portos secos distribuídos por toda a extensão da Capitania, dois dos quais estavam estabelecidos em Natal, e as guias de passagens eram diretamente emitidas pela Casa da Fazenda, totalizando assim 23 portos. Esse ofício traz a relação dos registros de Portos Secos e seus respectivos registradores estabelecidos nas passagens e lugares "para fornecerem guias aos condutores de Algodão da mesma Província que os levarem ao mercado das Províncias de Pernambuco, Paraíba e Ceará". ${ }^{30}$

Os Portos Secos foram estrategicamente dispostos nas imediações ribeirinhas, como o rio Apodi, Piranhas-Assu e Curimataú, ou mesmo nas próprias praias, como Guamaré e Touros. Esses portos eram os responsáveis pela comunicação econômica da Capitania do Rio Grande do Norte com o sistema -mundo econômico colonial. Foi através desses portos, e dos portos de Genipabu e Ponta Negra, que saíram da Capitania algodão, sal, couro, farinha e pau-brasil, os quais colocam o Rio Grande do Norte nos circuitos mercantis modernos. E por meio desses portos a Coroa estabeleceu seus administradores e cobrou seus impostos.

É interessante notar que a terminologia Portos Secos designou, no caso da Capitania do Rio Grande do Norte, pontos de vigilância mercantil pelas instituições coloniais e seus dispositivos de controle. Diante da lógica de controle estabelecida e dos mecanismos empregados pelas instituições coloniais 
aqui citadas, embora alguns dos Portos Secos mencionados fossem de fato portos marítimos - que historicamente receberam embarcações desde o avanço colonizador português, como o Porto de Água Maré (Guamaré) e Petitinga -, eles foram considerados pontos de vigilância e conferência de produtos que saíam da Capitania. Observa-se também que existiam portos em locais de proximidades fronteiriças, como a Serra de Luís Gomes, Serra das Almas e Patu. Embora não haja rios correndo próximo a essas localidades, elas encontram-se nas imediações das fronteiras da Capitania.

Ainda buscando estabelecer uma relação entre impostos e regulamentação trataremos, a partir de agora, do Imposto para o Benefício do Banco do Brasil. Instituído pelo Alvará Régio de 20 de outubro de 1812, o imposto deveria ser cobrado "por todas as compras e vendas de navios e embarcações de qualquer lote, à reserva unicamente de jangadas e barcos de pescarias, se pagará $5 \%$ do preço da compra, em todos os portos deste Estado do Brasil". ${ }^{31}$

Em virtude de o imposto ter entrado em vigor no final de 1812, somente no ano seguinte ele começou a ser cobrado na Capitania do Rio Grande do Norte. Como afirmamos anteriormente, os impostos não serviam apenas como dispositivos de arrecadação fiscal, mas como mecanismo de vigilância das práticas comerciais. Isso ocorre, a nosso ver, na própria dinamicidade com que a política fiscal portuguesa acabou incidindo sobre os espaços coloniais, já que, preocupados em firmar a mais nova instituição financeira do Reino Unido do Brasil, o Banco do Brasil, criaram um imposto de auxílio à sua fundação. Os comerciantes, mesmo cientes de sua carga tributária convencional, agora teriam de despender um novo tributo. Essa adequação à nova realidade acabava dinamizando a vigilância comercial, uma vez que, com o novo imposto, a Câmara iria revisitar todas as lojas e barcos para cobrar a nova taxa, caso já houvesse realizado essa vistoria anteriormente.

De acordo com o "Livro dos novos impostos", foram arrecadados no ano de 1813, para o Auxílio do Banco do Brasil, na Capitania do Rio Grande do Norte, 472\$200 réis, montante esse oriundo da cobrança de canoas, barcas, lojas de fazendas, secos e molhados e das lojas de ourives. Na cidade do Natal, a cobrança do novo imposto incidiu sobre 28 pessoas, das quais 14 eram donas de lojas de fazendas secas e molhadas, três eram proprietárias de lojas de ourives, dez possuíam canoas e uma delas possuía barca. Já na Vila da Princesa (atualmente Assu), cinco comerciantes foram cobrados, dos quais apenas um foi tributado por ter uma barca e todos os demais por possuir uma canoa. ${ }^{32}$ Nesse ano de 1813, seguiram 475\$200 réis da Capitania para a nova instituição 
financeira, quantia essa advinda do recolhimento da contribuição fiscal dos agentes mercantis.

Lojas, canoas e barcos. Em lugares fixos ou flutuantes em embarcações, os comerciantes e as comerciantes - como os casos de Joana Maria Damasceno da Glória e Thereza Antonia de Jesus, proprietárias de loja de gêneros secos e molhados em Natal, no início do século XIX - fomentavam o comércio colonial. Esses homens e mulheres, ao mesmo tempo que incidiam sobre as práticas do comércio, deveriam estar subjugados pela regulamentação desse mesmo comércio: pagar impostos era, e ainda é, condição regulamentada e obrigatória imposta pelo Estado.

Como último dispositivo institucional de regulamentação mercantil selecionado para essa análise, trataremos, agora, das arrematações de contratos.

A arrematação de contratos era um dos mecanismos usados pela Câmara para angariar recursos e atender às necessidades de abastecimento. Cabia à Câmara Municipal lavrar editais, colocando em "prassa” [sic], ou seja, em leilão, o contrato do fornecimento desses gêneros ou de serviços a serem prestados, que era concedido ao interessado que oferecesse maior valor por ele.

O sistema de contratos tem origem nos primórdios do Estado absolutista lusitano, constituindo uma forma de suprir a carência de recursos da Coroa e de envolver seus vassalos na gerência e assuntos da administração colonial. No geral, os contratos eram acordos temporários - tinham prazos determinados - da Coroa com particulares, sendo precedidos por arrematação e fixação do valor contratado. Tais práticas originaram-se dos monopólios régios, práticas mercantilistas típicas do Antigo Sistema Colonial em que estiveram sob contrato importantes fontes de rendimentos para a Coroa entre produtos e serviços necessários à efetiva administração do poder régio na América portuguesa. O gerenciamento das demandas coloniais a terceiros foi um processo iniciado desde a extração do pau-brasil através das feitorias, da divisão da colônia em Capitanias Hereditárias e da concessão de uso da terra por meio do sistema sesmarial.

$\mathrm{Na}$ condição de sócios temporários da Coroa, os contratadores atuavam como "braço" do aparelho estatal, representando uma das principais formas de articulação Estado/colonos, pressupondo uma prática monopolista. A Coroa se desonerava dos custos da montagem de um aparelho burocrático mais amplo, além de contar com uma renda certa por antecipação, visto que os contratos, uma vez arrematados, eram pagos antecipadamente à Coroa, ficando entregue à sorte a geração de lucro pelo contrato. 
Nas câmaras coloniais, normalmente, os contratos eram apregoados em praça pública para leilão por um funcionário específico, o porteiro, no final de cada ano ou início do seguinte. Ao pesquisar os negociantes e contratadores de algumas vilas da Capitania do Rio Grande do Norte nos manuscritos coloniais, percebemos que o processo de arrematação ocorria de forma sistemática e quase que exatamente igual em todos os contratos. Esse processo simbólico de transferência e alimentação desse poder - no universo dos contratos de arrematação, ou seja, o rito institucional - era iniciado com a anunciação da arrematação. Convocados em praça pública, à sombra da Casa de Câmara e ao lado do pelourinho, os vassalos, os oficiais e o porteiro iniciavam o ritual institucional. Em altas e inteligíveis vozes, o porteiro convocava os interessados a ofertarem; com olhares atentos ao público presente, buscando aqueles que mais ofertassem pelo contrato, o porteiro ameaçava: "já se arrematava, já se está arrematando, já estou metendo o ramo na mão". O porteiro anunciava aos oficiais que não havia mais quem oferecesse pelo contrato "e não havendo quem mais lançasse coisa alguma", os oficiais metiam o "ramo verde na mão do dito lançador", dizendo: "bom proveito lhe faça" ${ }^{33}$

O novo contratador aproximava-se dos oficiais do Senado, apresentava seu fiador, o escrivão tomava nota de tudo e estava finalizado o espetáculo da arrematação - o espaço institucional se faz operante sobre os colonos e sua prática espacial naquele instante em praça pública. O ritual é completo: gestos, movimentos e sons. Anúncio, comprometimento, entrega dos símbolos e assentamento de tudo nos Autos de Arrematação. Naquele ano de 1775, em que se arrematava o contrato dos subsídios de mel e aguardentes da cidade do Natal para o ano seguinte, apareceram Manoel de Araújo Monteiro que lançou 10 mil réis, depois Miguel Correa da Costa, lançando o dobro. Ganhou o último, apresentando como fiador José Jacques da Costa que afirmou ser de livre vontade e sem constrangimento algum ser avalista do amigo ou até parente de Miguel Correa da Costa, porém essa não era primeira vez em que Miguel Correa da Costa arrematava esse contrato e nem José Jacques era seu fiador, pressupondo uma prática patrimonialista nos contratos. ${ }^{34}$

Podemos destacar, nesse ritual, uma simbologia de transferência de direito e deveres encontrada em todos os documentos pesquisados que narram os processos de arrematação - a entrega de um ramo verde realizada no ato de finalização da arrematação, oferecido pelos oficiais da Câmara ao arrematante. Ao proclamar como arrematante aquele que deu o maior lance e a Câmara concordando com o valor, os oficiais entregavam um ramo verde acompanhado dos dizeres: "bom proveito lhe faça esse contrato". Esse ritual encerrava o 
processo simbólico da arrematação, podendo o arrematante empunhar o ramo verde ao alto para o público e passar a arrematação para os trâmites legais em que concordaria com as condições, apresentaria um fiador e assinaria o auto da arrematação.

Para o controle do comércio e abastecimento dos gêneros alimentícios, que eram apregoados em praça para arrematação, temos tipos de três contratos: aferições ou afilações, os molhados e as carnes.

Os contratos das aferições eram concedidos pelo prazo de um ano. $\mathrm{O}$ contratador das aferições responsabilizava-se pela vistoria dos pesos e medidas utilizados nos postos comerciais; ele deveria averiguar se as medidas utilizadas, pesos e marcas - para a comercialização da farinha, feijão, arroz e demais grãos - estavam concordantes com os pesos e medidas fornecidos pela Câmara e ditados pelo Código. O contrato dos molhados funcionava quase da mesma forma do das aferições. Concedido pelo prazo de um ano, a função do arrematante era cobrar o imposto sobre cada volume comercializado dos produtos, fossem eles em barris ou pipas; em alguns casos, requeria-se do fiador e do contratador a verificação, nos postos comerciais, dos volumes e medidas utilizados para a venda de mel e aguardente. Já o contrato das carnes era arrematado normalmente pelo prazo de 3 anos consecutivos. Concedida a licença, o contratador devia abastecer as localidades em dias específicos, conforme o estipulado pela Câmara. $\mathrm{O}$ arrematador era o único que poderia comercializar a carne, ficando a cargo da Câmara fazer vistoria na cidade e seu termo para inibir outros possíveis comerciantes de atuarem na oferta daquele produto.

Licenças para aberturas de lojas e colocação em prática de ofícios; impostos sobre comercialização de produtos, passagens, entradas e saídas; processos de arrematação para serviços e comércio de produtos - todos esses dispositivos fazem parte do universo regulamentador das práticas mercantis coloniais. Durante todo o período colonial e depois dele, em maior ou menor medida, todos os agentes mercantis - homens ou mulheres, comerciantes permanentes ou ambulantes - estiveram sob a égide normativa das instituições coloniais. Embora muitas vezes ocorra o descaminho, ou seja, a prática não permitida por esses agentes, eles foram constantemente pressionados pela regulamentação institucional.

Esmiuçados alguns dos mecanismos regulamentadores do comércio colonial, passemos ao exame dos mecanismos de vigilância, evidenciando os dispositivos utilizados para a fiscalização no cumprimento da norma esperada, pela Coroa, por seus vassalos. 
A excessiva preocupação do poder camarário sobre produtos e locais de comercialização visava controlar atitudes ilícitas que muitos comerciantes praticavam à procura de benefício próprio, como comercializar os gêneros com medidas ou pesos diferentes no intuito de burlarem o sistema de cobrança de impostos e, ao mesmo tempo, angariar maiores recursos.

Para efetivar essa fiscalização, a Câmara dispunha de funcionários específicos que participavam do cotidiano, deslocando-se aos locais de venda. Conhecedores das práticas comerciais rotineiras e dos esquemas usuais de burla dos comerciantes em relação às posturas, esses funcionários - revestidos do poder que lhes fora conferido ao assumirem um cargo real, isto é, legítimos representantes do rei nos domínios ultramarinos -, agiam de forma significativa para o efetivo controle dos colonos na América portuguesa. Eram os almotacés e os aferidores.

O almotacé foi instituído na América Portuguesa em 1532, com a fundação da Vila de São Vicente, conservando suas aptidões e deveres que lhes foram designados desde o Código Manuelino de 1521 (Salgado, 1985, p.135). Para escolha do ocupante desse cargo, na maioria das vezes, escolhia-se em sessão da Câmara um indivíduo que já havia servido no ano anterior, geralmente como juiz ordinário ou vereador. Essa prática era emblemática do tipo de ritos institucionais inerentes à Câmara: durante um ano, o oficial legislava e punia os transgressores na condição de vereador ou juiz; no ano seguinte, na função de almotacé, iria colocar em prática aquilo que anteriormente legislou como vereador.

Eram encarregados de executar tarefas específicas, principalmente a respeito das práticas mercantis. Inerente ao espaço institucional camarário, o almotacé esteve presente em todas as vilas da Capitania do Rio Grande do Norte. Para exemplificar sua atuação institucional com base na documentação camarária, escolhemos um aspecto de sua atuação enquanto sentinela do comércio colonial: a vigilância portuária e as denúncias de saída de víveres da Capitania.

Nas duas últimas décadas do século XVIII, houve intensos períodos de estiagem na Capitania do Rio Grande do Norte, notadamente nos anos de 1780 a 1785 e de 1790 a $1795 .{ }^{35}$ Um dos mecanismos utilizados pela Câmara para amenizar os efeitos da seca era recrudescer a vigilância nos portos de Natal, ora não permitindo a saída de víveres, ora obrigando as embarcações que entrassem a vender ao povo de Natal. O almotacé foi uma figura central no desenrolar dessas atividades. 
Na Vereação de 16 de dezembro de 1801, o almotacé da Câmara de Natal informa ter cumprido a "Portaria que proibia saída de gêneros de primeira necessidade". No entanto, ele estava sendo questionado em virtude de uma carta do governador-geral de Pernambuco, informando que aos portos de Recife "chegavam gêneros da Capitania do Rio Grande e por isso a cidade de Natal estava sofrendo, inclusive pelas lavouras que se degradavam, além dos muitos atravessadores". O almotacé defendeu-se proclamando que havia advertido "os atravessadores em geral e acusou o Capitão da Fortaleza ... de haver atravessado farinhas e comprado roçados". Os oficiais, por sua vez, "declararam que o Almotacé sempre cumprisse com suas obrigações ao útil e ao bem comum". ${ }^{36}$

A farinha de mandioca foi o produto de maior relevância econômica em matéria de produção, consumo e exportação para a Capitania. Numa média anual entre 1811 a 1813, foram exportados 6.967 alqueires de farinha, representando quase $24 \%$ da produção total de farinha daqueles anos. As vilas litorâneas de Extremoz, Arez, São José e Vila Flor comumente produziam a farinha exportada; ela também era fabricada na vila sertaneja de Portalegre, além de outras localidades (Lopes, 2005, Anexos, Tabela 18, p.678). Da mesma forma, o feijão e o arroz foram produtos de considerável exportação da Capitania, já que nos mesmos anos foram exportados 1.524 alqueires, representando quase 35\% da produção total. Com tão considerável produção e exportação, somente períodos de estiagem explicariam o fato de que, em 1796, o almotacé foi encarregado de fazer vistoria no porto de Natal e averiguar um barco que estava de saída "carregando farinha, feijão e arroz e que fizesse descarregar todo esse mantimento, deixando só o necessário à tripulação". ${ }^{37}$

Tal como o almotacé, o aferidor constituía um elemento primordial na vigilância das práticas comerciais. Estando munido dos pesos e medidas pertencentes à Câmara e regulado pelas Ordenações Filipinas, o aferidor deveria cotejar todos os pesos e medidas utilizados pelos vassalos nos engenhos, lojas, açougues ou tabernas. Sendo assim, aferidor "é o que coteja pelo padrão das medidas". A Câmara elege o aferidor e "lhe paga um tanto, porque é renda da própria Câmara e as partes lhe pagam um vintém, de cada aferição de medida, e duas vezes no ano, quando os Almotacés dão correição, senão acham as medidas aferidas, condenam aos donos". ${ }^{38}$

No Tomo I, Título XVIII, das Ordenações Filipinas, encontramos 28 artigos que discutem pontualmente a questão dos pesos e medidas. É de obrigação da Câmara possuir todos os padrões necessários ao cotejamento dos padrões utilizados pela população colonial, sendo obrigados a ter número diferenciados 
de padrões de acordo com o tamanho populacional das vilas e cidades. Os pesos deveriam ser guardados numa arca ou armário do Conselho, sendo que "os ditos Padrões não saíram fora da dita arca, somente para Casa de Câmara, quando forem necessários. E não os emprestaram a nenhuma pessoa, nem para por eles afilarem outros fora da Câmara, nem por eles pesarem" ${ }^{39}$

Na Cidade do Natal, em 1827, existiam seis mestres ourives; na Vila de São José, três mestres, quatro oficiais e três aprendizes; na Vila da Princesa, três mestres; e na Vila do Príncipe, um mestre ourives. ${ }^{40}$ Conforme as Ordenações, todos esses oficiais ourives deveriam ter em suas lojas "uma pilha [chama-se pilha certo número de pesos enconchados uns aos outros] de quatros marcos". ${ }^{41}$ Sendo assim, o aferidor teria de, pelo menos uma vez por ano, visitar todos esses mestres, oficiais e aprendizes, assim como suas respectivas lojas, examinando seus pesos e fazendo revista em suas balanças, para só assim passar um selo de aferição atestando a legitimidade de seus pesos.

Um segundo mecanismo institucional de vigilância do comércio eram as correições: uma interna e outra externa à Câmara. A correição interna é uma "expedição, em que vai o corregedor com seus oficiais pela comarca tomar conta de todos os malefícios". ${ }^{42}$ Quando os Corregedores encontravam-se nas câmaras pertencentes à jurisdição de sua comarca, deveriam "ouvir os camaristas, questionando sobre a ação do Senado no âmbito de sua jurisdição". Além desses aspectos pertinentes à gerência municipal da ordem, inquiria-se sobre "a frequência dos vereadores nas sessões da Câmara, as eleições de Almotacé e, de maneira mais incisiva, notadamente durante o período pombalino, perguntas sobre a arrematação das rendas" (Sousa, 2005, p.315). Averiguavam-se também os assentos institucionais da Câmara, como livros, papéis e provimentos; preparavam-se, caso estivesse em tempo, as listas de votação de pelouro.

O segundo tipo de correição é o externo, ou seja, no espaço institucional abrangido pela Câmara. Nessa correição, em que "fazem as Câmaras e Almotacés, que é irem pelos lugares de sua jurisdição, para verem se as testadas das fazendas estão feitas e os agoeiros abertos". "Fiscalizar testadas e agoeiros", na verdade, são metáforas usadas por Rafhael Bluetau para englobar um sem -número de práticas inspecionadas e corrigidas durante uma correição camarária em sua jurisdição: verificar as licenças de oficiais de ofícios; locais de lojas e suas respectivas permissões; pesos e medidas utilizados nas lojas, tabernas e açougues; preços praticados; procurar os vadios e mal procedidos. O método utilizado nas correições implicava a busca de testemunhas que narrassem sobre 
os transgressores das posturas e, sendo examinados os ditos das testemunhas, caçavam os transgressores e condenavam-nos.

As correições camarárias eram realizadas pelo menos uma ou duas vezes no ano e, caso coincidisse a realização da correição camarária com a chegada do Corregedor, este participava da correição. Correição, portanto, possui dois significados distintos que corroboram um rito institucional enquanto mecanismo relevante à vigilância do comércio. Correição é "andar o corregedor em correição"; ${ }^{43}$ é correr os lugares, povoados, vilas e caminhos em busca de corrigir, censurar, repreender e punir.

\section{PARA ALÉM DAS APARÊNCIAS COTIDIANAS}

Embora haja uma aparente distinção entre aqueles que eram oficiais de ofícios mecânicos e os negociantes, é possível afirmar que, na maioria das vezes, aqueles que exerciam determinados tipos de ofício eram os mesmos que mantinham lojas abertas ou comercializavam em suas casas e oficinas. Esse foi o caso, por exemplo, dos ourives e boticários. Para esses oficiais e negociantes,

o Código Filipino exigia que possuíssem, em seu poder, pesos e medidas específicos.

Consta num mapa populacional de 1806 que havia no Rio Grande do Norte, naquele ano, 177 negociantes, perfazendo pouco mais que $0,3 \%$ do total da população apresentada na carta. ${ }^{44}$ Poucos anos depois, num Mapa Estatístico compilado entre 1811 e 1813, existiam na Capitania 469 negociantes, representando quase $1 \%$ da população total apresentada no documento. ${ }^{45}$ De uma contagem populacional para outra, num intervalo de aproximadamente 7 anos, a população absoluta da Capitania só havia aumentado em 1.238 habitantes, ao passo que o número de negociantes praticamente triplicou.

Embora tenhamos consciência das incertezas e flexibilizações com as quais devemos analisar toda essa documentação, acreditamos que esses números demonstram a atração, sempre crescente, que as práticas mercantis vieram a incitar nas sociedades modernas. Esses negociantes, cujos produtos de comercialização não foram identificados nos mapas populacionais apresentados, seja qual fosse sua ocupação mercantil ou produto comercializado, eram regulados e vigiados.

Diante do quadro exposto - mecanismos de regulamentação e vigilância das práticas mercantis -, compreendemos a centralidade das câmaras enquanto normatizadoras do espaço institucional. Verificamos também que as câmaras coloniais incorporaram todos os segmentos e mecanismos institucionais 
capazes de institucionalizar espaços, corpos e mentes. A linguagem institucional própria das câmaras advém dos registros escritos deixados pelo escrivão, quando ele deixa transparecer o léxico próprio como descaminhos, correição ou mesmo Senado da Câmara. Os privilégios aparecem, por exemplo, no caso das mulheres que conseguiram licença para abrir suas lojas por terem uma conduta aceitável. As cerimônias são exemplificadas pelos ritos de arrematação e de correição. Ambos os processos trazem símbolos, emblemas e hierarquias diferenciadas. A norma provém do Código Filipino, da fabricação das posturas e das obrigações impostas aos agentes mercantis. Por fim, a punição é exemplar no processo de mortificação: condenados em réis e prisão durante correição ou por fabricar e vender sem licença.

Linguagem, privilégios, cerimônias, normas e punição constituíram uma fórmula perfeita, encontrada pelas Câmaras Municipais das vilas da Capitania do Rio Grande do Norte, para reproduzirem o poder reinol no litoral e no sertão e, especialmente, sobre homens e mulheres, livres ou escravos, brancos, negros ou índios. Sem fugir à regra, os agentes mercantis foram incessantemente regulamentados e vigiados, no entanto, nem sempre institucionalizados totalmente.

\section{REFERÊNCIAS}

ALMEIDA, Cândido Mendes de. Ao leitor. In: Auxiliar jurídico, v.1. Lisboa: Fundação Calouste Gulbenkian, s.d., p.5. Ao leitor. In: CÓDIGO Filipino, ou, Ordenações e Leis do Reino de Portugal: recompiladas por mandado d'el-Rei D. Filipe I. Ed. fac-similar da 14a ed. de 1821 / por Cândido Mendes de Almeida. Brasília: Senado Federal, Conselho Editorial, 2004. (Edições do Senado Federal, v.38).

BLUTEAU, Rafhael. Verbete "Aferidor”. In: Vocabulario portuguez \& latino: aulico, anatomico, architectonico... Coimbra: Collegio das Artes da Companhia de Jesus, $1712-1728.8 \mathrm{v}$.

. Verbete "Correicam". In: . Vocabulário Portuguez \& latino..., 1712-1728. $8 \mathrm{v}$.

DIAS, Thiago Alves et al. Secas coloniais. A escassez de alimentos e o Senado da Câmara de Natal no final do século XVIII. PubliCa, v.4, p.10-24, 2008.

LOPES, Fátima M. Em nome da liberdade, as vilas de índios do Rio Grande do Norte sob o diretório Pombalino no século XVIII. Tese (Doutorado em História) - Programa de Pós-Graduação em História, Universidade Federal de Pernambuco (UFPE). Recife, 2005. 
RIBEIRO JÚNIOR, José. Colonização e monopólio no Nordeste brasileiro. São Paulo: Hucitec, 2004.

SALGADO, Graça (Org.) Fiscais e meirinhos: a administração no Brasil colonial. Rio de Janeiro: Nova Fronteira; Arquivo Nacional, 1985.

SILVA, Francisco Ribeiro da. Alfândegas lusas em finais de setecentos: fiscalidade e funcionalismo. In: O LITORAL em perspectiva histórica (séc. XVI a XVIII). Cidade do Porto: Instituto de História Moderna, 2002.

SOUSA, Avanete Pereira. Poder local e autonomia camarário no Antigo Regime: o Senado da Câmara da Bahia (séc. XVIII), In: BICALHO, Maria Fernanda B.; FERLINI, Vera L. do A. Modos de Governar: ideias e práticas políticas no Império português (séc. XVI a XIX). São Paulo: Alameda, 2005.

WESTPHALEN, Cecília Maria. Verbete: Registro. In: SILVA, Maria Beatriz Nizza da (Org.) Dicionário da colonização portuguesa no Brasil. Lisboa: Verbo, 1994. p.691-692.

\section{NOTAS}

${ }^{1}$ Instituto Histórico e Geográfico do Rio Grande do Norte (IHGRN), Livro de Termo de Vereação do Senado da Câmara de Natal (LTVSCN), Termo de Vereação (TV) de 29 dez. 1682, cx. 03, lv. 1674-1698, fl. 49.

${ }^{2}$ IHGRN, LTVSCN, TV de 21 jan. 1683, cx. 03, lv. 1674-1689, fl. 50.

${ }^{3}$ IHGRN, LTVSCN, TV de 16 out. 1723, cx. 01, lv. 1721-1735, fl. 30.

${ }^{4}$ CÓDIGO Filipino, vol. 1, f. 144-153.

${ }^{5}$ IHGRN, LTVSCN, TV de [s/d/m] de 1798, cx.02, lv. 1784-1803, fl. 109-109v.

${ }^{6}$ IHGRN, LTVSCN, TV de s/d jan. 1682, cx. 03, lv. 1674-1698, fl. 42v-43.

${ }^{7}$ IHGRN, LTVSCN, TV de 5 jul. 1679, cx. 03, lv. 1674-1698, fl. 29v.

${ }^{8}$ IHGRN, LTVSCP, TV de 24 mar. 1777, cx. Cartas e Provisões (CP) nº 6, lv. Câmara de Portalegre, 1771 a 1794.

${ }^{9}$ IHGRN, CP, cx. 04, lv. 12. Registro de 6 nov. 1782.

${ }^{10}$ Idem.

${ }^{11}$ Biblioteca Nacional do Rio de Janeiro (BNRJ), I - 32, 10, 5. Doc. 13.

${ }^{12}$ BNRJ, I - 32, 10, 5. Doc. 12.

${ }^{13}$ IHGRN, RCPSCN, cx. 05, lv. 15.

${ }^{14}$ IHGRN, LTVSCN, TV de 19 jan. 1713, cx. 01, lv. 1709-1721, fl. 07-07v e TV de 2 abr. 1717, cx. 01, lv. 1709-1721, fl. 110.

${ }^{15}$ IHGRN, LTVSCN, TV de 2 abr. 1717, cx. 01, lv. 1709-1721, fl. 110v. 
${ }^{16}$ IHGRN, LTVSCN, TV de 1 jun. 1719, cx. 01, lv. 1709-1721, fl. 125v-126.

${ }^{17}$ IHGRN, LTVSCN, TV de 1 set. 1719, cx. 01, lv. 1719, fl. 01-01v.

${ }^{18}$ IHGRN, LTVSCN, TV de 28 fev. 1684, cx. 03, lv. 1674-1698, fl. 57v-58.

${ }^{19}$ IHGRN, LTVSCN, TV de 4 fev. 1697, cx. 03, lv. 1674-1698, fl. 135v-136-136v-137.

${ }^{20}$ IHGRN, LTVSCN, TV de 24 set. 1674, cx. 03, lv. 1674-1698, fl. 03-03v.

${ }^{21}$ IHGRN, LTVSCN, TV de 24 set. 1678, cx. 03, lv. 1674-1698, fl. 22-22v.

${ }^{22}$ IHGRN, LTVSCN, TV de 1 abr. 1689, cx. 03, lv. 1674-1698, fl. 85.

${ }^{23}$ IHGRN, LTVSCN, TV de 25 set. 1750, cx. 01, lv. 1745-1752, fl. 95-96.

${ }^{24}$ Arquivo Nacional do Rio de Janeiro (AN), Série Vice-Reinado, cód. fundo: D9, notação: CX. 761, doc. 20, secção CODES.

${ }^{25}$ Arquivo Histórico Ultramarino (AHU)_ACL_CU_018, Cx. 9, D. 623.

${ }^{26}$ RIBEIRO JÚNIOR, 2004, p.72; AHU_ACL_CU_018, Cx. 9, D. 623; BNRJ, I - 32, 10, 5. Doc. 12.

${ }^{27}$ AN, Série Interior, Cód. fundo: AI, notação: IJJ2-433, CODES. Decreto de criação da Alfandega de Inspeção do Algodão de 3 fev. 1820.

${ }^{28}$ AN, Série Interior, Cód. Fun.: AI, Not.: IJJ2-433, Seç.: CODES.

${ }^{29}$ AN, Série Interior, Cód. Fun.: AI, Not.: IJJ2-433, Seç.: CODES.

${ }^{30}$ AN, Série Interior, cód. fundo: AI, notação: IJJ2-433, Secção: CODES, p. 274.

${ }^{31}$ CÓDIGO Filipino, lv. 02, leis extravagantes, p. 510-511.

32 IHGRN, Livro dos novos impostos 1813, cx. Impostos (1728-1732).

${ }^{33}$ IHGRN, LCASCN, Auto de 22 nov. 1775, cx. contrato das carnes, lv. 1776, fl. 01-02.

${ }^{34}$ IHGRN, LCASCN, Auto de 22 nov. 1773, cx. Contrato das carnes, lv. 1771. fl 15v, -16v.

${ }^{35}$ Sobre o assunto ver: DIAS, 2008.

${ }^{36}$ IHGRN, LTVSCN, TV de 16 dez. 1785, cx. 02, lv. 1784-1803, fl. 04.

${ }^{37}$ IHGRN, LTVSCN, TV de s/d/m de 1796, cx. 02, lv. 1784-1803, fl. 71-71v.

${ }^{38}$ BLUTEAU, Verbete “Aferidor”, 1712-1728, p.148.

${ }^{39}$ CÓDIGO Filipino, lv.1 tit. XVIII, $\$ 36$ a $\$ 40$.

${ }^{40}$ BNRJ, I - 32, 10, 5. Doc. 13.

${ }^{41}$ CÓDIGO Filipino, lv.1 tit. XVIII, $\$ 42$.

${ }^{42}$ BLUTEAU, Verbete "Correicam”, 1712-1728, p.563.

${ }^{43}$ BLUTEAU, Verbete "Correicam”, 1712-1728, p.564.

${ }^{44}$ AHU_ACL_CU_18, CX. 9, D. 623.

${ }^{45}$ BNRJ, I - 32, 10, 5. Doc. 12.

Artigo recebido em 7 de outubro de 2011. Aprovado em 22 de outubro de 2014. 